\title{
Pemberdayaan Remaja Melalui Inovasi Pembuatan Permainan Congkak Berbasis Digital Pada Komunitas Permainan Tradisional Di Desa Tanjung Rejo Kecamatan Percut Sei Tuan Kabupaten Deli Serdang
}

\author{
Rosramadhana $^{1}$, Sudirman $^{2}$, Zulaini $^{3}$ \\ ${ }^{1}$ Prodi Pendidikan Antropologi, Fakultas Ilmu Sosial \\ ${ }^{2}$ Jurusan Pendidikan Masyarakat, Fakultas Ilmu Pendidikan \\ ${ }^{3}$ Jurusan Ilmu Keolahragaan, Fakultas Ilmu Keolahragaan, Universitas Negeri Medan, Medan
}

Email : rosramadhana@unimed.ac.id

\begin{abstract}
Abstrak - Permainan tradisional adalah salah satu produk budaya yang dimiliki bangsa Indonesia dan dienkulturasikan dari satu generasi ke generasi berikutnya. Memperkenalkan permainan tradisional dapat berdampak positif disebabkan makna dari nilai pendidikan yang bercirikan kultur bangsa Indonesia. Di negara yang memiliki kultur ketimuran seperti di Indonesia, permainan tradisional memiliki ciri khas dan tergantung budaya dari berbagai etnis yang melestarikan permainan tradisional tersebut. Di Indonesia permainan tradisional yang dilestarikan diantarnaya adalah congkak . Permainan ini memiliki nama yang berbeda dari berbagai etnis di Indonesia. Di daerah Jawa permainan ini lebih dikenal dengan nama dhakon, sedangkan di Sumatera disebut dengang nama congkak. Metode pelaksanaan dalam kegiatan yang dilaksanakan adalah untuk mencari alternatif solusi dari permasalahan mitra khususnya dalam memberdayaan remaja dilakukan melalui empat tahapan yaitu perencanaan, organisasi, aktualisasi, serta pengawasan. Pelaksanaan program kegiatan ini menghasilkan pembuatan inovasi permainan congkak berbasis digital seperti poster digital,animasi, inovasi permainan congkak dan pembuatan akun youtobe. Kegiatan ini memberdayakan remaja khususnya dalam memperkuat budaya lokal dan nilai budaya melalui permainan tradisional yang inovatif dan mengasah kreativitas remaja melalui teknologi tepat guna.
\end{abstract}

Kata kunci : permainan tradisional, congkak, kearifan lokal, nilai budaya

\begin{abstract}
Traditional games are one of the cultural products possessed by the Indonesian people and have been cultured from one generation to the next. Introducing traditional games can have a positive impact due to the meaning of educational values characterized by Indonesian culture. In Indonesia, traditional games have characteristics and depend on the culture of various ethnicities that preserve these traditional games. In Indonesia, the traditional game that is preserved between them is arrogant. This game has different names from various ethnic groups in Indonesia. In Java this game is better known as dhakon, while in Sumatra it is called congkak. The method of implementation in the activities carried out is to find alternative solutions to partner problems, especially in empowering adolescents through four stages, namely planning, organization, actualization, and supervision. The implementation of this activity program resulted in the creation of digital-based arrogant game innovations such as digital posters, animation, arrogant game innovation and the creation of a youtobe account. This activity empowers adolescents, especially in strengthening local culture and cultural values through innovative traditional games and honing youth creativity through appropriate technology.
\end{abstract}

Keywords: traditional games, congkak, local wisdom, cultural values

\section{PENDAHULUAN}

Permainan tradisional saat ini kembali diinventarisasi menjadi agenda khusus Kementerian Pendidikan dan Kebudayaan Republik Indonesia (Kemendikbud RI) yang bekerjasama dengan kementerian lainnya. Hal ini dilakukan sebagai upaya menggali nilai-nilai budaya yang melekat pada permainan tradisional tersebut. Selain itu tujuannya adalah menghidupkan pekan kebudayaan untuk memperkenalkan budaya nusantara sejak dini kepada anak-anak Indonesia. Program kementerian ini belum terealisasi karena mengalami hambatan disebabkan merebaknya wabah virus covid 19 di berbagai belahan dunia bahkan di Indonesia.

Permainan tradisional merupakan sebuah permainan rakyat yang dapat membangkitkan semangat dalam memainkannya. Saat ini permainan tradisional kurang diminati. Hal ini disebabkan anak-anak dan remaja saat ini cenderung menyukai dan menggemari pemainan modern yang canggih 
dan virtual seperti game online. Permainan rakyat merupakan permainan yang dapat memberi kesempatan santai dan memiliki unsur kesehatan jasmani [1]. Berdasarkan kemajuan era digital yang begitu pesat dalam teknologi menjadikan anak-anak dan remaja saat ini tidak lagi menyukai permainan yang berbasis budaya warisan leluhur tersebut. Hal ini dapat terlihat berdasarkan fakta di masyarakat bahwa anak-anak dan remaja cenderung kurang mengetahui beragam permainan tradisional yang masih nampak bahkan relatif tidak menyukai dan berkeinginan mengupas potensi budaya lokal di lokasi tempat mereka bermain dan bertempat tinggal.

Permainan tradisional sebagai warisan tak benda yang diberikan secara turun temurun merupakan aset yang harus dijaga. Dalam permainan tradisional bermakna dan mempunyai nilai edukasi yang harus ditanamkan agar tetap melekat dan sesuai kultur bangsa Indonesia [2]. Di Indonesia permainan tradisional beraneka ragam dan memiliki khas budaya dari berbagai etnis yang melestarikan permainan tradisional tersebut. Permainan tradisional merupakan keunikan budaya yang dilestarikan. Satu dari banyak permainan tradisional adalah congkak. Permainan ini memiliki nama yang berbeda dari berbagai etnis di Indonesia. Di Jawa permainan ini lebih dikenal dengan nama dhakon, sedangkan di Sumatera disebut dengan nama congkak [3]. Permainan congkak ini merupakan permainan tradisional yang memiliki sarat makna dan unsur nilai karakter yang relevan untuk dimainkan anak-anak.

Memainkan congkak sebenarnya cukup mudah, seorang memainkannya dengan cara duduk berhadapan. Permainan dilakukan secara bergantian dan saling menunggu. Pada saat memulai permainan dilakukan kesepakatan dan tidak dilakukan undian namun biasanya dengan cara sut terlebih dahulu agar mendapatkan kesempatan memulai permainan. Permainan dijalankan secara bersamaan dan jika pemain satu lebih cepat mengisi rumahnya kemudian dia bergerak mendahului lawannya. Pemain boleh memulai permainan congkak dari mana lubang yang dipilih. Pada lubang congkak jika ada 1, 2, 3, 4, 5, 6 dan 7 lubang, maka ada tujuh buah batu atau lainnya dalam setiap lubang yang akan dimasukkan. Total jumlah buah yang diperlukan adalah $7 \times 7=49$. Kemudian diambil semua batu atau buah dalam lubang yang disukai dan lakukan pergerakan mengikuti arah pusingan jam dan seterusnya diulang kembali. Pada saat bergerak, pemain memasukkan satu buah batu ke dalam setiap lubang yang dilalui dan "rumah induk" (lubang besar di ujung). Hanya satu lubang indukyang dimasukkan bagi setiap pemain antara lain lubang induk di ujung, selanjutnya di sebelah kiri pemain tersebut.
Peminatan terhadap permainan congkak masih kurang. Hal ini karena kurangnya pewarisan budaya dari keluarga kepada generasi saat ini. Namun sejalan dengan berkurangnya kepedulian terhadap permainan tradisional masih didapatkan adanya sebuah komunitas khusus mewariskan permainan tradisional dari Indonesia. Komunitas tersebut bernama Komunitas Petra (Permainan Tradisional). Komunitas ini berada di Desa Tanjung Rejo Kecamatan Percut Sei Tuan Kabupaten Deli Serdang. Berdirinya komunitas tersebut atas inisiator tokoh pendidikan yang bekerjasama dengan Pusat Kegiatan Belajar Masyarakat (PKBM) Laskar Pelangi pada tahun 2019. Komunitas Petra saat ini diketuai oleh Muhammad Siddik Zailani dan beranggotakan anak-anak dan remaja sebanyak 15 (lima belas) orang. Adapun tujuan didirikannya komunitas ini adalah untuk membangun kembali permainan tradisional yang sudah lama ditinggalkan [4].

Komunitas Petra didirikan namun belum memiliki tempat khusus untuk melatih kemampuan anak-anak dan remaja dalam permainan tradisional secara khusus. Permainan dilaksanakan pada halaman rumah ketua Komunitas Petra. Program kegiatan yang dilaksanakan sebelum merebaknya covid-19 juga masih berbasis bantuan dan kerjasama dari berbagai pihak. Berikut gambaran keberadaan dari Komunitas Petra:
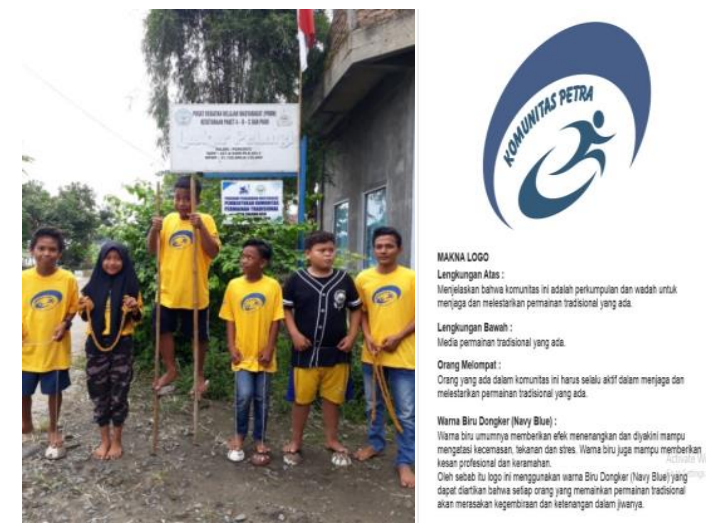

Gambar 1. Komunitas Petra sedang berlatih engrang, egrang dan yeye

Keberadaan Komunitas Petra saat ini menjadi sangat penting namun anggotanya didominasi kaum remaja yang tidak lepas dari dunia teknologi. Komunitas ini harus menyesuaikan keberadaaan mereka sebagai generasi milenial yang identik dengan kecanggihan teknologi. Komunitas Petra belum mempunyai modal untuk mengembangkan potensi mereka dalam pemanfaatan teknologi untuk memperkenalkan permainan tradisional yang dilakukan secara langsung, sehingga kesulitannya adalah mengajak 
anak-anak dan remaja lainnya ikut berpartisipasi dalam permainan tradisional yang mereka rintis. Selain itu Komunitas Petra memiliki potensi dalam pembuatan properti permainan tradisional sendiri khususnya membuat egrang, engrang, meriam bambu, layang-layang dan yeye. Berikut gambar pembuatan properti dari Komunitas Petra.
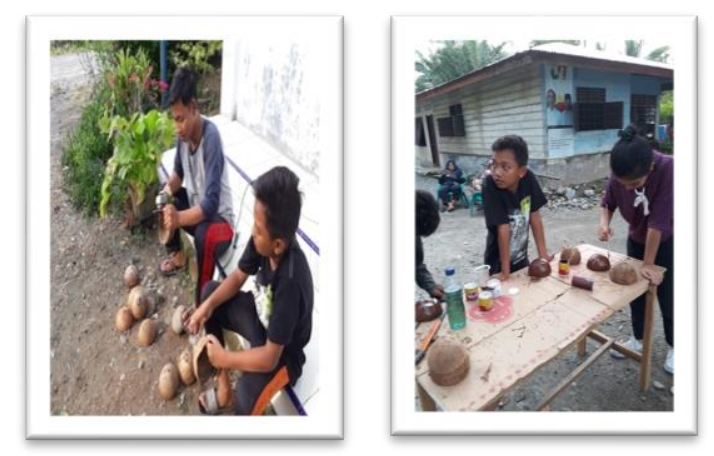

Gambar 2. Komunitas Petra membuat egrang

Berdasarkan dari analisis terhadap situasi mitra dan penguatan terhadap pewarisan budaya agar tetap eksis sebagai upaya dalam menjaga sebuah aset bangsa yang berbentuk wujud tak benda seperti permainan tradisional congkak khususnya diperlukan adanya pemberdayaan kepada komunitas remaja sebagai pewaris generasi muda bangsa Indonesia. Program yang dilakukan dengan melatih membuat inovasi permainan congkak secara digital melalui pembuatan poster, animasi dan pembuatan youtube untuk memperkenalkan hasil karya inovasi remaja Komunitas Petra. Kegiatan ini bertujuan agar remaja dapat melanjutkan pembangunan berkesetaraan yang dapat menjunjung tinggi harkat dan martabat bangsa yang teguh dan berkeadilan.

\section{METODE PELAKSANAAN}

Metode menjadi acuan dalam pelaksanaan program yang mengarah kepada indikator ketercapaian yang terukur. Metode pelaksanaan kegiatan dalam menuntaskan solusi dari permasalahan dengan melakukan pendampingan yang berkesinambungan dan pembinaan dalam permainan tradisional pada remaja di Komunitas Petra Desa Tanjung Rejo Kecamatan Percut Sei Tuan. Kegiatan ini dilakukan dengan prosedur kerja yang sesuai untuk mekanisme pembuatan alat tepat guna kepada mitra. Berikut merupakan diagram mekanisme alur dalam pelaksanaan program kegiatan yang dilakukan melalui 4 (empat) tahapan antara lain perencanaan, organisasi, aktualisasi, serta pengawasan.

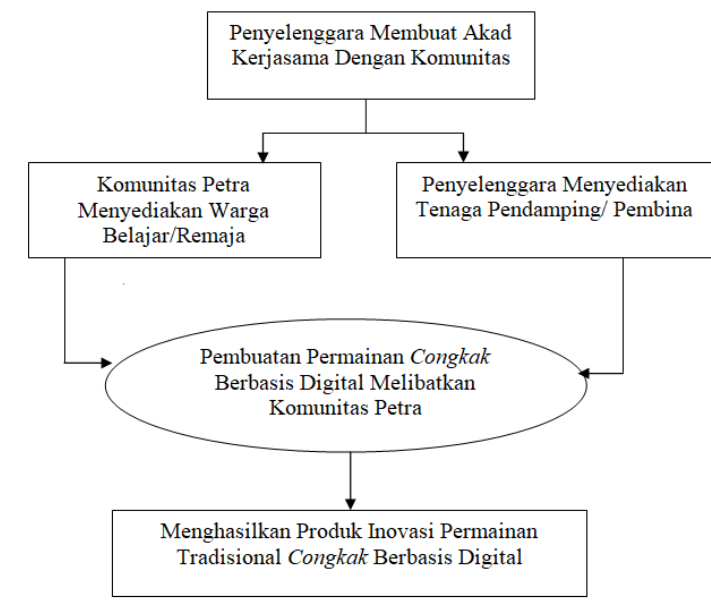

Gambar 3.Prosedur kerja pendampingan

Pelaksanaan Kegiatan yang telah dilakukan adalah sebagai berikut :

a. Survei Kelompok Sasaran

Pada tahap pertama melakukan peninjauan lokasi yang akan dijadikan sasaran dalam penerapan Program Pengabdian Masyarakat untuk mendapatkan informasi terhadap kegiatan yang akan dikembangkan.

b. Identifikasi Kebutuhan Program

Pada tahap ini mematangkan kembali konsep yang telah dirumuskan, terutama terkait dengan program yang akan dilaksanakan dan identifikasi kebutuhan remaja dalam kegiatan pembuatan permainan congkak

c. Persiapan Sarana dan Prasarana

Tahap ini merupakan tahap mempersiapkan sarana dan prasarana yang akan mendukung program ini. Sebagai langkah awal difokuskan pada ketersediaan bahan untuk permainan congkak berbasis digital.

d. Pelaksanaan Proses Pembuatan Congkak dan Pembinaan

Pada tahap Pelaksanaan, dilakukan pelatihanpelatihan dalam upaya melestarikan permainan rakyat melalui pembuatan congkak. Muatan program yang paling penting dalam program ini adalah memberikan sosialisasi kepada masyarakat dan khususnya orang tua sebagai kelompok sasaran dalam pelaksanaan.

e. Evaluasi

Pada tahap evaluasi, warga masyarakat yang terlibat dan kelompok remaja Komunitas Petra diberikan feedback tentang program yang telah dilaksanakan. Hal ini menjadi pertimbangan bagi kontinuitas program ke depannya

Tahapan proses pelatihan dan pengembangan produksi dapat dilihat pada gambar 4 . 


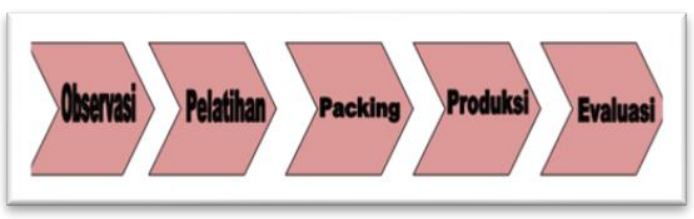

Gambar 4. Proses pelatihan dan pengembangan oleh Komunitas Remaja dalam inovasi pembuatan congkak berbasis digital [5]

\section{HASIL DAN PEMBAHASAN}

Kegiatan program pengabdian pada masyarakat sudah terlaksana pada Komunitas Permainan Tradisional (Petra) di Desa Tanjung Rejo Kecamatan Percut Sei Tuan. Adapun hasil program pengabdian kepada masyarakat tersebut dapat diuraikan sebagai berikut :

\section{a. Pelaksanaan sosialisasi}

Sosialisasi dilakukan pada Komunitas Permainan Tradisional Di Desa Tanjung Rejo Kecamatan Percut Sei Tuan Kabupaten Deli Serdang pada 18 Juli 2020. Kegiatan ini dilakukan tetap dengan mematuhi protokol kesehatan yang dianjurkan oleh pemerintah. Hal ini dilaksanakan untuk memberikan penjelasan awal tentang permainan congkak serta pembuatan inovasi digital. Dalam kegiatan ini juga disampaikan pembuatan permainan congkak berbasis digital melalui gadget, sehingga komunitas dapat mengakses dan membuat inovasi yang menarik dan dapat disimpan di akun mereka masing-masing. Memanfaatkan gadget dengan baik dan tepat guna khususnya dalam mempelajari dan memperkenalkan permainan congkak melalui teknologi memudahkan anak-anak remaja terhindar dari kecanduan game online yang tidak mendidik dan akan membahayakan perkembangan otak.

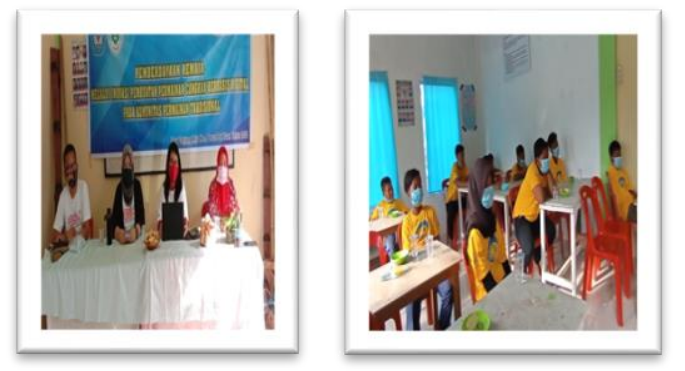

Gambar 5. Sosialisasi program pembuatan permainan congkak berbasis digital

\section{b. Pendampingan pembuatan inovasi poster digital congkak}

Kegiatan dilaksanakan pada tanggal 09 Agustus 2020. Pada tahap ini dilakukan kegiatan pre test untuk mengukur kemampuan pengetahuan remaja tentang permainan tradisional congkak. Tim mempersiapkan soal dan kunci jawaban dan selanjutnya dievaluasi oleh tim yang juga didampingi oleh mitra. Selanjutnya tim memberikan materi sebagai penguatan terhadap pengetahuan permainan tradisional khususnya congkak. Sehabis melakukan kegiatan pretest proses pendampingan pembuatan poster digital dilaksanakan. Tim bersama mahasiwa melatih remaja Komunitas Petra menggunakan aplikasi/software MS Powerpoint dan aplikasi PicArt. Bahan yang digunakan dan diolah di dalam aplikasi merupakan gambar dan desain yang sesuai dengan dongeng yang ingin dimuat dengan format .png (gambar tanpa latar belakang/transparan) untuk menambah artistik. Tindakan selanjutnya adalah menata dan menentukan tata letak, memilih font, ukuran font dan warna yang sesuai.

Adapun langkah-langkahnya, pertama siapkan dan buka aplikasi powerpoint hingga muncul tampilan. Kemudian membuat pola menggunakan menu insert dan klik shapes bertanda panah dibawah. Klik dan bentuk shapes yang telah dipilih di kanvas power point, seperti di Gambar 6. Tambahkan gambar png yang telah disiapkan dan desain sedemikian rupa, sesuai keinginan.
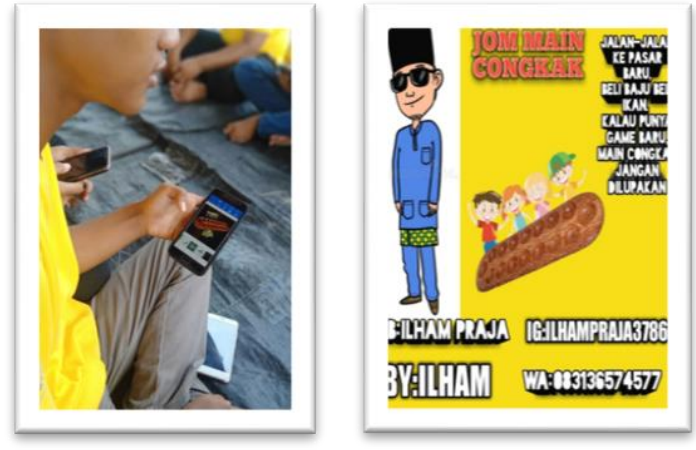

Gambar 6. Proses pembuatan poster congkak dengan inovasi digital

\section{c. Pembuatan inovasi congkak dalam bentuk animasi}

Dilaksanakan pada tanggal 26 September 2020. Pelaksanaan kegiatan ini bertujuan memperkuat kreativitas remaja Komunitas Petra dalam menggunakan teknologi digital tepat guna khususnya untuk permainan tradisional congkak. Kegiatan dilakukan tim bersama mahasiswa. Dalam Membuat animasi peserta di ajarkan untuk mengolah dan mendesain alur cerita melalui aplikasi/software berupa aplikasi pengedit video seperti filmora, kinemaster, dan plotagon. Peserta diarahkan dan dibimbing untuk menggunakan ketiga aplikasi tersebut dalam membuat animasi, baik memasukkan file karakter, background dan suara. Kemudian menyusun alur cerita dan export file sehingga menjadi sebuah video. 

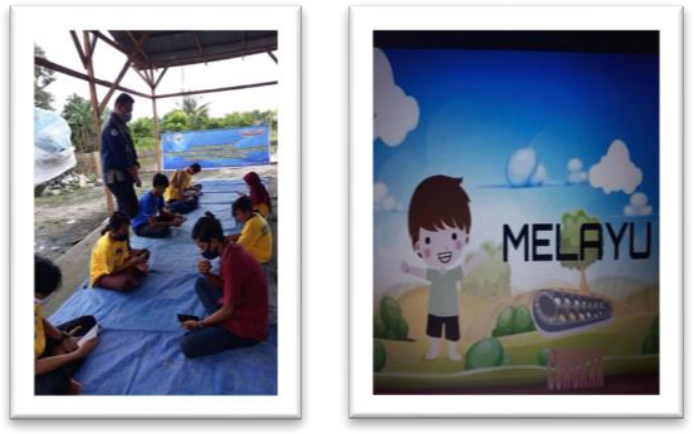

Gambar 7. Proses pembuatan congkak dengan inovasi animasi digital

\section{d. Pelaksanaan permainan congkak}

Dilaksanakan pada tanggal 9 Oktober 2020 dengan melibatkan tim, mitra dan komunitas dengan tujuan untuk melatih remaja bermain congkak agar tidak melupakan waisan budaya tersebut. Kegiatan ini juga diinovasi dengan mengajak komunitas bermain congkak dengan diiringi musik Melayu sebagai upaya dalam melestarikan budaya lokal di Sumatera Utara. Aktivitas bermain congkak yang dilakukan tim bersama Komunitas Petra dengan tetap mengikuti protokol kesehatan agar terhindar dari penyebaran virus covid 19 yang masih tinggi pada saat pelaksanaan kegaitan. Dari kegiatan tersebut terlihat bahwa remaja belum semuanya menguasai permainan berdasarkan aturan permainan congkak yang telah ditetapkan secara resmi, namun sangat bersemangat dan mulai mengenal permainan congkak tersebut sebagai budaya Melayu di Sumatera Utara.
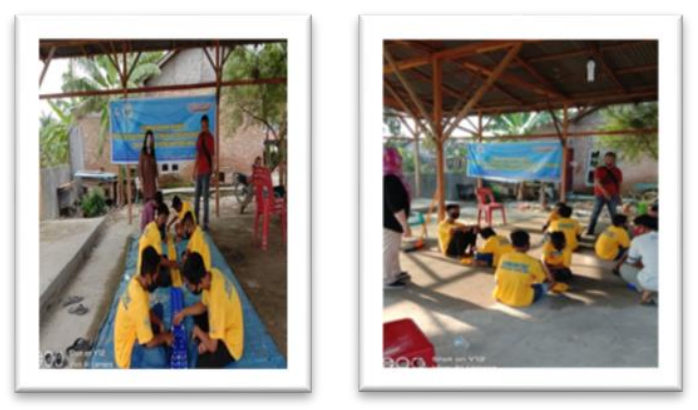

Gambar 8. Pelaksanaan permainan congkak dengan protokol kesehatan

\section{e. Pembuatan inovasi congkak dalam akun youtube}

Dilaksanakan pada tanggal 24 Oktober 2020. Kegiatan ini merupakan langkah terakhir dalam pembuatan congkak digital. Kegiatan ini dilakukan secara daring oleh pendamping dan dibantu oleh ketua Komunitas Permainan Tradisional Tanjung
Rejo. Pembuatan akun congkak dengan tujuan agar remaja pada komunitas tidak hanya mempu bermain dan membuat inovasi permainan congkak, akan tetapi dapat menyebarkan warisan budaya ini melalui jaringan teknologi agar tetap dikenal generasi saat ini.

Pembuatan akun youtube menggunakan email yang telah dimiliki baik dengan nama sendiri/ custom. Hal terpenting dalam pembuatan akun youtube adalah email, bagi yang belum memiliki email silahkan untuk membuat email di laman https://accounts.google.com > signup. Setelah email sudah ada, langkah berikutnya adalah login ke aplikasi youtube dengan menggunakan email tersebut dengan cara membuka aplikasi. Email secara otomatis sudah tertaut dengan akun youtube, sehingga tidak perlu mendaftar.
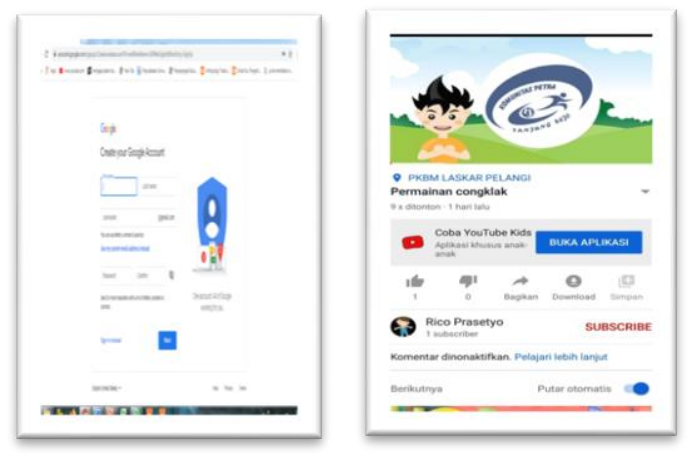

Gambar 9. Pembuatan akun youtobe untuk menyimpan dan menyebarkan pembuatan inovasi congkak digital

\section{f. Monitoring dan evaluasi}

Pada kegiatan ini ketercapaian dalam pelaksanaan program khususnya dalam inovasi permainan tradisional dapat diukur berdasarkan indikator yang telah ditetapkan. Selain itu, tim juga melihat ketercapaian permainan congkak di lokasi Komunitas Permainan (mitra). Dari hasil evaluasi dan monitoring yang dilaksanakan dapat dijelaskan bahwa mitra menjalankan program ini secara terus menerus dan sesuai program yang dirancang dan disepakati. Komunitas Petra telah berhasil menambah kreativitas bermain congkak yang menarik dan mengikuti perlombaan congkak.

Berdasarkan analisis program kegiatan yang terlaksana memiliki dampak yang positif khususnya dalam mengembangkan permainan tradisional berbasis digital.

Berdasarkan hasil pre test yang dilakukan terhadap 20 orang remaja, nilai yang diperoleh menunjukkan 8 orang mendapatkan nilai 60 . Dengan diberikan penguatan, pembinaan dan pendampingan secara terorganisir selama 3 (tiga) bulan disamping terus melakukan evaluasi secara berkelanjutan, dapat terlihat kemajuan yang cukup 
signifikan dan terukur. Berdasarkan hasil post test yang dilakukan didapatkan 12 orang remaja berhasil memperoleh nilai 80. Komunitas Petra sudah diberdayakan, juga berdampak pada kepemilikan akun youtube yang dapat memberikan pengaruh positif dalam memperkenalkan permainan tradisional ini.

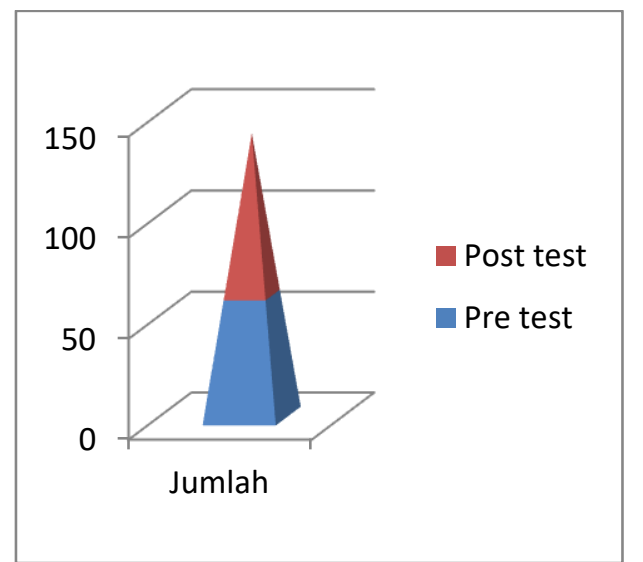

Gambar 10. Grafik tingkat kemampuan remaja membuat inovasi permainan congkak berbasis digital

\section{SIMPULAN}

Program Kemitraan Masyarakat yang dilaksanakan sebagai bentuk kegiatan pengabdian kepada masyarakat tersebut sudah dijalankan selaras dengan mekanisme pelaksanaan program. Kegiatan dilakukan dari sosialisasi sampai terlaksananya program inti. Capaian program kegiatan pengabdian kepada masyarakat ini adalah tersedianya inovasi pembuatan congkak berbasis digital pada komunitas Permainan Tradisional dan keberlanjutan program komunitas dengan beragam permainan tradisional lainnya. Tujuan dari program untuk memberdayakan remaja khususnya dalam memperkuat budaya lokal melalui permainan tradisional yang inovatif telah tercapai. Kegiatan ini juga mengasah kreativitas remaja melalui teknologi tepat guna. Kegiatan ini dapat menghasilkan karya inovasi remaja berbentuk poster digital, animasi dan akun youtube sebagai upaya pelestarian budaya lokal mengikuti perkembangan era teknologi.

\section{UCAPAN TERIMA KASIH}

Ucapan terima kasih khususnya disampaikan untuk Lembaga Penelitian dan Pengabdian Masyarakat (LPPM) Unimed yang telah memberikan bantuan dan dukungan untuk melakukan kegiatan pengabdian tersebut. Terima kasih kepada mitra Komunitas Permainan Tradisional, PKBM Laskar Pelangi dan jajaran pemerintahan Desa Tanjung Rejo yang telah bekerjasama untuk berpartisipasi dalam menuntaskan program tersebut, sehingga Komunitas Permainan Tradisional bisa tetap eksis memperkenalkan dan melestarikan permainan tradisional dengan mengikuti perkembangan zaman di era digital saat ini.

\section{DAFTAR PUSTAKA}

[1]. Zulaini, dkk. 2020. Modifikasi Alat Ladder Drill Berdasarkan Alat Permainan Tradisional Rangku Alu. SENASPA PPA 1. ISSN : 2716-3024

[2]. Sudirman, dkk. 2019. Pendampingan Pembentukan Komunitas Remaja Dalam Pelestarian Permainan Tradisional Berbahan Batok Kelapa di PKBM Laskar Pelangi Desa Tanjung Rejo Kecamatan Percut Sei Tuan. Prosiding Seminar Nasional Hasil Penelitian dan Pengabdian Kepada Masyarakat ( LPPM) ISBN 978-602-501-311-9

[3]. Portal Informasi Indonesia. 2019. Serunya Bermain Congklak. Indonesia.go.id diakses 20 November 2020

[4]. Sudirman, dkk. 2020. Pemberdayaan Komunitas Remaja Dalam Melestarikan Permainan Tradisional Egrang di Desa Tanjung Rejo Kecamatan Percut Sei Tuan. SENASPA PPA Vol 1. ISSN : 2716-3024

[5]. Wulandari, Fenny, dkk. 2019. Pendampingan Anak-anak Mengenal Sejarah Lokal Berbasis Digital Folklore di Kecamatan Medan Barat. Jati Emas (Jurnal Aplikasi Teknik Dan Pengabdian Masyarakat). 3(2) - e. ISSN: 2550-0821 